\title{
Перфоративна гастродуоденальна виразка. Вибір методики операції
}

\begin{abstract}
Мета роботи: проаналізувати результати хірургічного лікування і якость життя хворих, оперованих із приводу перфоративної гастродуоденальнї виразки.

Матеріали і методи. Робота базується на аналізі результатів хірургічного лікування 261 хворого 3 перфоративною гастродуоденальною виразкою. Переважали хворі працездатного віку: у віці до 60 років було 235 (90 \%) осіб. Середній вік хворих складав 38,7 року.

Залежно від виду операції усі хворі були розподілені на дві групи. Першу групу склали 159 хворих, яким виконана операція висічення виразки з пілоропластикою без ваготомії, другу - 102 хворі, яким виконана операція висічення виразки з ваготомією. Для обстеження хворих були використані такі методи: клінічний аналіз крові, клінічний аналіз сечі, біохімічне дослідження, групи крові, резус-фактора, електрокардіографія, рентгенологічне дослідження органів черевної порожнини та грудної клітки. Були визначені такі гематологічні індекси: лейкоцитарний індекс інтоксикації (ЛІІ), ядерний індекс зсуву (ЯІЗ), а також відношення нейтрофілів до лімфоцитів (Н/Л).

Результати досліджень та їх обговорення. Аналіз показав, що в усіх випадках мала місце перфорація хронічної виразки. 3ロясовано, що у віддалені терміни у оперованих хворих слизова оболонка шлунка мала морфологічні особливості, характерні для хронічного атрофічного гастриту з вогнищами повної кишкової метаплазії. При хірургічному лікуванні хворих на перфоративну гастродуоденальну виразку рекомендовано виконувати висічення виразки з виконанням пілоропластики та проведенням медикаментозної коригуючої терапії.
\end{abstract}

Ключові слова: виразкова хвороба; перфоративна гастродуоденальна виразка; якість життя.

Постановка проблеми і аналіз останніх досліджень та публікацій. Поширеність виразкової хвороби в Україні як і раніше не має тенденції до зниження, а ускладнення, що виникають, часто загрожують життю хворого й потребують невідкладного оперативного втручання. Зростає кількість невідкладних оперативних утручань при проривних виразках, а післяопераційна летальність складає 3,44 \%. Актуальність проблеми перфоративної пілородуоденальної виразки зумовлена і різноманіттям лікувально-тактичних підходів. Впровадження в клінічну практику лікування виразкової хвороби блокаторів $\mathrm{H}_{2}$ гістамінових рецепторів, інгібіторів протонного насосу, антихелікобактерної терапії потребують перегляду хірургічних методик [1]. Невирішення проблеми полягає у відсутності на даний час єдиної думки щодо вибору оптимального способу хірургічного втручання. Вважається, що вибір певного методу оперативного втручання і його радикальність багато в чому залежить від конкретної клінічної ситуації, віку хворого, супутньої патології, ступеня операційного ризику [2, 3]. Ефективність хірургічних методів лікування захворювань, у тому числі і перфоративної виразки, визначається в основному за такими показниками, як летальність, тривалість перебування в стаціонарі, наявністю післяопераційних ускладнень, а також частотою та ступенем виразності різних розладів, що реєструються лабораторними та інструментальними методами досліджень у віддаленому періоді $[4,5]$.
Мета роботи: проаналізувати результати хірургічного лікування і якість життя хворих, оперованих із приводу перфоративної гастродуоденальної виразки.

Матеріали і методи. Робота базується на аналізі результатів хірургічного лікування 261 хворого $з$ перфоративною гастродуоденальною виразкою. Переважали хворі працездатного віку: у віці до 60 років було 235 (90 \%) осіб. Середній вік хворих складав 38,7 року.

Залежно від виду операції усі хворі були розподілені на дві групи. Першу групу склали 159 хворих, яким виконали операцію висічення виразки з пілоропластикою без ваготомії, другу - 102 хворих, яким виконано операцію висічення виразки з ваготомією.

Для обстеження хворих використано такі методи: клінічний аналіз крові, клінічний аналіз сечі, біохімічне дослідження, групи крові, резусфактора, електрокардіографія, рентгенологічне дослідження органів черевної порожнини та грудної клітки. Були визначені такі гематологічні індекси: лейкоцитарний індекс інтоксикації (ЛІІ), ядерний індекс зсуву (ЯІЗ), а також відношення нейтрофілів до лімфоцитів (Н/Л).

При обстеженні хворих у віддалені терміни проводилась фіброгастродуоденоскопія 3 прицільною біопсією з трьох точок (тіло шлунка, пілороантральна зона, дуоденум). Для визначення 
активності хронічного гастриту та наявності атрофії використовували візуально-аналогову шкалу. Оцінка морфологічних змін слизової оболонки шлунка проводилася відповідно до СіднейськоX'юстонської класифікації хронічних гастритів (1996). Для виявлення Helicobacter pylori (Hр) проводилось фарбування за Гімза. Виявляли три ступені контамінації слизової оболонки: слабкий ступінь (+) - 20 мікробних тіл у полі зору при збільшенні 630; середній ступінь (++) - від 20 до 50 мікробних тіл у полі зору; високий ступінь (+++) більше 50 мікробних тіл у полі зору.

Якість життя хворих вивчена на основі розробленої нами анкети. Відповідаючи на запитання анкети, хворий мав указати чи виникає в його житті в зв’язку з хворобою необхідність будь-яких обмежень: необхідність дотримуватися дієти, необхідність обмежень у трудовій діяльності, фізичному навантаженні, статевих відносинах. Анкета має контрольний перелік питань для виявлення можливих симптомів хвороби, з'ясування загального стану респондента, його шкідливих звичок, супутніх захворювань, питання відносно проведення профілактичного лікування, обстеження в післяопераційному періоді. Усі анкетовані розподілені за терміном після операції (1 рік, 2-5 років, більше 5 років) та за методикою виконаної операції.

Результати досліджень та їх обговорення. У хворих першої групи після оперативного втручання ускладнення виникли у 24 (15 \%) хворих. У 3 (1,89 \%) хворих було нагноєння післяопераційної рани; у 5 (3,14 \%) розвинулась клініка гострої шлунково-кишкової кровотечі, яка була зупинена проведенням консервативної гемостатичної терапії. Уповільнення відновлення функції шлунково-кишкового тракту спостерігали у 2 (1,26 \%) хворих, клініка порушення евакуації зі шлунка спостерігалась у 5 (3,14 \%), при цьому 3 хворих потребували повторного оперативного втручання - релапаротомії 3 накладенням гастроентероанастомозу. Пневмонія спостерігалась у 3 (1,89%) хворих, явища ексудативного плевриту - у 4 (2,52 \%). У 1 (0,63 \%) хворого розвинулась гостра спайкова непрохідність тонкої кишки, що потребувало виконання релапаротомії; гострий тромбофлебіт глибоких вен гомілки розвинувся в 1 (0,63 \%) хворого.

У хворих другої групи після оперативного втручання ускладнення виникли у 23 (22,5 \%) хворих. У 2 (1,96 \%) хворих було нагноєння післяопераційної рани. Гостра шлунково-кишкова кровотеча розвинулася у 2 (1,96 \%) хворих, вона була зупинена проведенням консервативної гемостатичної терапії. Післяваготомну атонію шлунка спостерігали у 9 (8,8\%) хворих: після виконання СПВ - 4 (3,92 \%) хворих, СВ - 3 (2,9 \%), у 2 (1,96 \%) хворих після комбінованої ваготомії. Проведена консервативна терапія привела до компенсації евакуаторної функції шлунка. Пневмонію було діагностовано у 3 (2,9 \%) хворих, явища ексудативного плевриту в 1 (1,02 \%), у 3 (2,9 \%) розвинувся пневмоторакс, що потребувало дренування плевральної порожнини за Бюлау. Гостра динамічна кишкова непрохідність розвинулась в 1 (0,98 \%) хворого, гострий тромбофлебіт глибоких вен гомілки в 1 (0,98 \%) хворого, інфаркт міокарда в 1(0,98 \%) хворого. Таким чином, у хворих другої групи спостерігались ускладнення, що пов'язані з виконанням ваготомії - пневмоторакс, атонія шлунка, яких не було у хворих першої групи.

Окремо слід зазначити, що у кожного дев’ ятого хворого була наявна друга виразка “дзеркальна виразка” на задній стінці дуоденум, що вимагало виконання екстеріоризації виразки. Безумовно, подібна частота потребує включення в обстеження хворого перед операцією ФГДС, особливо це актуально, коли планується проведення лапароскопічної операції, під час якої можливості проведення ревізії обмежені.

На нашу думку, лапароскопічні методи на даний час не слід розглядати в якості стандартного лікування. Вважаємо, що лапароскопічне втручання при перфоративній виразкі можливо у пацієнтів молодого віку з перфоративним отвором меньше 5 мм, місцевим перитонітом і при наявності відповідних лапароскопічних навичок у хірургів та обстеження хворого включно ФГДС.

Проведено гістологічне дослідження інтраопераційного матеріалу (виразкового дефекту й періульцерозної зони) у 152 хворих, із них 89 хворих першої та 63 хворих другої групи. Морфологічні зміни, виявлені у всіх спостереженнях, відповідали хронічній виразці з явищами загострення процесу, про що свідчила наявність фіброзу різних ділянок стінки шлунка та дванадцятипалої кишки в зоні локалізації виразкового дефекту. Фіброз був найбільш виражений у підслизовому шаpi. Крім того, мав місце склероз стінок дрібних судин дна виразки. Внутрішня стінка дна виразки утворена фібринозно-слизовим детритом, рясно інфільтрованими полінуклеарами. На межі зони детриту й зони фіброзу виявляються різко набряклі, місцями фрагментовані, деконтуровані еозинофільні колагенові волокна.

Таким чином, в усіх аналізованих випадках мала місце перфорація хронічної виразки, на що вказують ознаки хронічного запалення: наявність 


\section{З ДОСВІДУ РОБОТИ}

сполучної рубцевої тканини, утворення лімфоїдно-плазмоцитарної інфільтрації, деструкція та тромбоз мікроциркуляторного русла з крововиливами в навколишні тканини. Виявлені зміни зумовлюють необхідність висічення виразки під час операції.

У віддалений термін гістологічно було досліджено біопсійний матеріал від 23 хворих. В першій групі було 13 обстежених, у другій - 10. При морфологічному дослідженні гастро- і дуоденобіоптатів хворих першої групи у віддалений термін Нр в слизовій оболонці шлунка виявлено у 5 (38,4 \%) пацієнтів, при цьому слабкий ступінь інфікованості був у 3 випадках, в одному середній ступінь та в одному високий ступінь контамінації слизової оболонки. У хворих другої групи контамінація слизової оболонки Нр виявлена у 5 (50 \%) пацієнтів: слабкий ступінь інфікованості був у 4 випадках, в одному - середній ступінь.

Для осіб першої групи домінуючою формою змін, що спостерігались у слизовій оболонці антрального відділу шлунка, був хронічний помірно виражений атрофічний неактивний гастрит, що супроводжується зменшенням кількості залоз, без відсутності вираженого набряку власної пластинки й наявності запального інфільтрату, що поширювався до середини гландулярного шару слизової оболонки, без ознак наявності Нр (5 (38,4%) випадків). На тлі цього спостерігалися вогнища повної кишкової метаплазії у 10 (76,9 \%) хворих. При цьому типі метаплазії спостерігалася більшість клітинних типів кишкового епітелію, але наявність серед них клітин Панета дозволила віднести її до тонкокишкового типу. У 3 (23,1%) випадках була виявлена неповна кишкова метаплазія.

У хворих другої групи зміни слизової оболонки антрального відділу шлунка відповідали хронічному помірно вираженому атрофічному неактивному гастриту без асоціації з Нр (4 випадки (40 \%)). Питома вага повної кишкової метаплазії, яка супроводжувала вищезазначені зміни, складала 80 \%, неповної кишкової метаплазії 20 \%.

При вивченні біоптатів слизової оболонки, вилучених із тіла шлунка пацієнтів першої групи, було встановлено, що в 9 (69,3 \%) випадках запальні зміни були мінімальними, з них 38,5 \% склали випадки поверхневого гастриту та 30,8 \% випадки початкового атрофічного гастриту.

У хворих другої групи поверхневий гастрит зустрічався в 40 \% випадків, початковий атрофічний гастрит - у 30 \% обстежених хворих.

При дослідженні дуоденобіоптатів у пацієнтів першої та другої груп домінували прояви хронічного дуоденіту першого ступеня (по 75 \% випадків).
Таким чином, слизова оболонка пілороантрального відділу шлунка мала морфологічні особливості, характерні для хронічного помірно вираженого неактивного неасоційованого з Нр атрофічного гастриту з вогнищами повної кишкової метаплазії; для тіла шлунка найбільш характерним був стан, що відповідає морфологічній картині поверхневого та початкового атрофічного неасоційованого з Нр атрофічного гастриту; у слизовій оболонці дванадцятипалої кишки найчастіше виявлявся неактивний хронічний дуоденіт першого ступеня. Розподіл форм хронічного гастриту та дуоденіту, виявлений за допомогою морфологічного дослідження біоптатів у першій та другій групі, були тотожними. Відзначена незначна варіабельність не була статистично значущою. Ці дані слід ураховувати при плануванні консервативної терапії в післяопераційному періоді. Висока питома вага повної кишкової метаплазії свідчить про порушення процесів репарації у хворих на виразку, що потребує диспансерного нагляду. Слід зазначити, що за даними N. Uernura та співавторів (2001) при обстеженні 1526 хворих інфікованих Нр рак шлунка у віддалені терміни було виявлено у 3 \% випадків, але при цьому автори вказують, що рак виявляли у випадках конкретної гістологічної картини: тяжкої шлункової атрофії, переважно атрофічного гастриту тіла шлунка та наявності кишкової метаплазії.

При вивченні якості життя хворих у термін 1 рік після операції на біль в животі висувають скарги (57 \%) респондентів першої групи, а у хворих другої групи скарг на біль у животі не було $(\mathrm{p} \leq 0,001)$.

Обмежують себе у фізичних навантаженнях у зв’язку з виразковою хворобою 43 \% анкетованих першої групи та 50 \% другої групи. У зв’язку 3 виразковою хворобою дотримуються дієти 57 \% хворих першої групи та 75 \% - другої групи, усі вони обмежують себе у виборі продуктів та страв постійно ( $>0,05)$.

Жоден із респондентів першої та другої групи терміном 1 рік після операції не проходив лікування та фіброгастродуоденоскопію.

У термін 2-5 років після операції на біль у животі скаржаться 42,3 \% респондентів першої групи, 48,4 \% - у другій. Обмежують себе в фізичних навантаженнях у зв'язку з виразковою хворобою 38,4 \% анкетованих першої групи та 38,4 \% другої групи (p>0,05). У зв'язку з виразковою хворобою дотримуються дієти 34,6 \% першої групи та 32,3 \% - другої групи. Профілактичне лікування проходили 19,2 \% опитаних першої групи та 32,3 \% - другої групи. Стаціонарне лікування про- 
йшли 19,2 \% респондентів першої групи та 19,4 \% - другої групи.

Отже, при аналізі якості життя хворих, оперованих з приводу перфоративної гастродуоденальної виразки як з ваготомією, так і без неї в терміни з другого року та більш віддалений період, не встановлено статистично достовірної різниці між скаргами хворих. Необхідність обмежень у повсякденній життєдіяльності, суспільному та особистому житті однакова в обох групах хворих.

Висновки. 1. У хворих з перфоративною гастродуоденальною виразкою має місце перфорація хронічної виразки, на що вказують ознаки хронічного запалення: наявність сполучної рубцевої тканини, утворення лімфоїдно-плазмоцитарної інфільтрації, деструкція та тромбоз мікроциркуляторного русла з крововиливами в навколишні тканини. Виявлені зміни зумовлюють необхідність висічення виразки під час операції. Перфорація виразки розвивається на тлі наявних змін слизової оболонки.

2. У віддалені терміни після операції з приводу перфоративної гастродуоденальної виразки спостерігаються виражені морфологічні зміни слизової оболонки: слизова оболонка пілороантрального відділу шлунка мала морфологічні особливості, характерні для хронічного помірно вираженого неактивного неасоційованого з Нр атрофічного гастриту з вогнищами повної кишкової метаплазії; для тіла шлунка найбільш характер-

\section{СПИСОК ЛІТЕРАТУРИ}

1. Афендулов С. А. Стратегия хирургического лечения язвенной болезни / С. А. Афендулов, Г. Ю. Журавлев, А. Д. Смирнов // Хирургия. - 2006. - № 4 (27). - С. 129-134. 2. Русин В. І. Комплексне лікування перфоративних пілородуоденальних виразок з урахуванням гелікобактеріозу та стану кислотності шлунка / В. І. Русин, Ю. М. Фатула // Науковий вісник Ужгородського університету. Серія “Медицина". - 2004. - Вип. 22. - С. 151-156.

3. Фомін П. Д. Еволюція лікувальної тактики при кровоточивих гастродуоденальних виразках / П. Д. Фомін, В. Д. Братусь, В. І. Нікішаєв // Науковий вісник Ужгородського уні-

\section{REFERENCES}

1. Afendulov, S.A., Zhuravlev, G.Yu., \& Smirnov, A.D. (2006). Strategiya khirurgicheskogo lecheniya yazvennoy bolezny [Surgical treatment strategy for peptic ulcer]. Khirurgiya - Surgery, 4 (27), 129-134 [in Russian].

2. Rusyn, V.I., \& Fatula, Yu.M. (2004). Kompleksne likuvannia perforatyvnykh piloroduodenalnykh vyrazok z urakhuvanniam helikobakteriozu ta stanu kyslotnosti shlunka [Complex treatment of perforative pyloroduodenal ulcers taking into account helicobacteriosis and gastric acidity]. Naukovyi visnyk Uzhhorodskoho ним був стан, що відповідає морфологічній картині поверхневого та початкового атрофічного неасоційованого з Нр атрофічного гастриту; у слизовій оболонці дванадцятипалої кишки найчастіше виявлявся неактивний хронічний дуоденіт першого ступеня. Висока питома вага повної кишкової метаплазії свідчить про порушення процесів репарації у хворих на виразку, що потребує диспансерного нагляду.

3. Через 2-5 років після оперативного лікування перфоративної гастродуоденальної виразки як з ваготомією, так і без неї, клінічні прояви хвороби, необхідність обмежень в трудовій діяльності, фізичному навантаженню однакова у обох групах хворих. Відмічається низька медична активність і зацікавленність у власному здоров'ї респондентів як першої, так і другої групи, незалежно від методу операції.

4. Вибір методу операції визначається віком хворого, локалізацією виразки, тривалістю виразкового анамнезу, виразністю морфологічних змін з боку виразки і навколишніх тканин, особливостями кислотоутворювальної функції шлунка, а також тяжкістю стану хворого, який зумовлений наявністю прогресуючого перитоніту, гемодинамічними порушеннями і супутньою патологією. При хірургічному лікуванні хворих на перфоративну гастродуоденальну виразку рекомендовано виконувати висічення виразки з виконанням пілоропластики та проведенням медикаментозної коригуючої терапії.

верситету. Серія “Медицина”. - 2003. -Вип. 20. - С. 81-84 4. Морфология слизистой желудка и качество жизни больных с перфоративными гастродуоденальными язвами в отдалённые сроки после оперативного лечения / В. О. Сипливий, В. В. Доценко, О. Г. Петюнін, С. В. Грінченко // Сучасні медичні технології. - 2011. - № 3-4 (11-12). - С. 354-357.

5. Сипливий В. О. Хірургічне лікування і якість життя хворих на перфоративну гастродуоденальну виразку : монографія / В. О. Сипливий, В. В. Доценко, О. В. Євтушенко. - Харків : ХНАДУ, 2015. - 108 с

universytetu. Seriia "Medytsyna" - Uzhhorod University Scientific Bulletin. Series "Medicine", 22, 151-156 [in Ukrainian].

3. Fomin, P.D., Bratus, V.D., \& Nikishayiev, V.I. (2003). Evoliutsiia likuvalnoi taktyky pry krovotychyvykh hastroduodenalnykh vyrazkakh [Evolution of therapeutic tactics in hemorrhage gastroduodenal ulcers]. Naukovyi visnyk Uzhhorodskoho universytetu. Seriia "Medytsyna" - Uzhhorod University Scientific Bulletin. Series "Medicine", 20, 81-84 [in Ukrainian].

4. Syplyvyy, V.O., Dotsenko, V.V., Petyunin, O.H., \& Grinchen- 
ko, S.V. (2011). Morfologiya slyzystoy zheludka i kachestvo zhyzni bolnykh s perforatyvnymi gastroduodenalnymi yazvami v otdalennye stroki posle operativnogo lecheniya [Morphology of the gastric mucosa and the quality of life of patients with perforated gastroduodenal ulcers in the long term after surgical treatment]. Suchasni medychni tekhnolohii. Vseukrainska naukovo-praktychna konferentsiia z mizhnarodnoiu uchastiu - Modern Medical Tech- nologies. All-Ukrainian Scientific-practical Conference with International Participation, 3-4 (11-12), 354-357 [in Russian]. 5. Syplyvyi, V.O., Dotsenko, V.V., \& Yevtushenko, O.V. (2015). Khirurhichne likuvannia i yakist zhyttia khvorykh na perforatyvnu hastroduodenalnu vyrazku: monohrafiia [Surgical treatment and quality of life of patients with perforative gastroduodenal ulcer: monograph]. Kharkiv: KHNADU [in Ukrainian].

Отримано 01.11.2019

Електронна адреса для листування: syplyviy@ukr.net

V. O. SIPLYVY, V. V. DOTSENKO, G. D. PETRENKO, A. G. GUZ, S. V. GRINCHENKO

Kharkiv National Medical University

\title{
PERFORATIVE GASTRODUODENAL ULCER. CHOICE OF OPERATION METHOD
}

The aim of the work: to analyze the results of surgical treatment and quality of life of patients operated on perforative gastroduodenal ulcer. Materials and Methods. The work is based on the analysis of the results of surgical treatment of 261 patients with perforated gastroduodenal ulcer. Patients of working age predominated: there were 235 (90 \%) people under 60 years of age. The average age of patients was 38.7 years.

Depending on the type of surgery, all patients were divided into two groups. The group I consisted of 159 patients who underwent surgery for excision of the ulcer with pyroplasty without vagotomy, group 2-102 patients who underwent surgery for excision of the ulcer with vagotomy.

The following methods were used for the examination of patients: clinical blood test, clinical urine analysis, biochemical study, blood groups, rhesus factor, electrocardiography, radiological examination of abdominal and chest organs. The following hematologic indices were identified: leukocyte intoxication index (LII), nuclear displacement index (NID), and the ratio of neutrophils to lymphocytes (N/L). Results and Discussion. The results of surgical treatment of 261 patients with perforated gastric and duodenal ulcers were analysed. The analysis had shown that in all cases was present chronic ulcer perforation. It was found out, that patients operated in remote terms had morphological peculiarities of gastric mucous membrane, such as chronic atrophic gastritis with focuses of complete intestinal metaplasia. At surgical treatment of patients with perforated gastroduodenal ulcers the excision of ulcer with pyloroplasty and therapeutic correcting treatment is recommended.

Key words: ulcerous disease; perforated gastroduodenal ulcer; life quality.

\section{В. А. СИПЛИВЫЙ, В. В. ДОЦЕНКО, Г. Д. ПЕТРЕНКО, А. Г. ГУЗЬ, С. В. ГРИНЧЕНКО}

Харьковский национальный медицинский университет

\section{ПЕРФОРАТИВНАЯ ГАСТРОДУОДЕНАЛЬНАЯ ЯЗВА. ВЫБОР МЕТОДИКИ ОПЕРАЦИИ}

\begin{abstract}
Цель работы: проанализировать результаты хирургического лечения и качества жизни больных, оперированных по поводу перфоративной гастродуоденальной язвы.

Материалы и методы. Работа базируется на анализе результатов хирургического лечения 261 больного с перфоративной гастродуоденальной язвой. Преобладали больные трудоспособного возраста: в возрасте до 60 лет было 235 (90 \%) человек. Средний возраст больных составлял 38,7 лет.

В зависимости от вида операции все больные были разделены на две группы. Первую группу составили 159 больных, которым выполнена операция иссечение язвы с пилоропластикой без ваготомии, вторую - 102 больных, которым выполнена операция иссечение язвы с ваготомией.

Для обследования больных были использованы следующие методы: клинический анализ крови, клинический анализ мочи, биохимическое исследование, группы крови, резус-фактора, электрокардиография, рентгенологическое исследование органов брюшной полости и грудной клетки. Были определены следующие гематологические индексы: лейкоцитарный индекс интоксикации (ЛИИ), ядерный индекс сдвига (ЯИС), а также отношение нейтрофилов к лимфоцитам (Н/л).

Результаты исследований и их обсуждение. Проведен анализ результатов оперативного лечения 261 больного с перфоративной язвой желудка и двенадцатиперстной кишки. Анализ показал, что во всех случаях имела место перфорация хронической язвы. Выяснено, что в отдаленные сроки у оперированных больных слизистая оболочка желудка имела морфологические особенности, характерные для хронического атрофического гастрита с очагами полной кишечной метаплазии. При хирургическом лечении больных перфоративной гастродуоденальной язвы рекомендуется выполнять иссечение язвы с выполнением пилоропластики и проведением медикаментозной корректирующей терапии.
\end{abstract}

Ключевые слова: язвенная болезнь; перфоративная гастродуоденальная язва; качество жизни. 